\title{
Euglycaemic hyperinsulinaemia does not affect gastric emptying in Type I and Type II diabetes mellitus
}

\author{
M.-F. Kong ${ }^{1}$, P. King ${ }^{1}$, I. A. Macdonald ${ }^{2}$, P. E. Blackshaw ${ }^{3}$, M. Horowitz ${ }^{4}$, A. C. Perkins ${ }^{3}$, E. Armstrong Ar $^{5}$ \\ K.D. Buchanan ${ }^{5}$, R. B. Tattersall ${ }^{1}$ \\ ${ }^{1}$ Diabetes Unit, University Hospital, Queen's Medical Centre, Nottingham, UK \\ ${ }^{2}$ School of Biomedical Sciences, University of Nottingham Medical School, Nottingham, UK \\ ${ }^{3}$ Department of Medical Physics, University Hospital Nottingham and University of Nottingham Medical School, \\ Nottingham, UK \\ ${ }^{4}$ Department of Medicine, Royal Adelaide Hospital, Adelaide, South Australia \\ ${ }^{5}$ Department of Medicine, Royal Victoria Hospital, Belfast, UK
}

Summary Hyperglycaemia slows gastric emptying in both normal subjects and patients with diabetes mellitus. The mechanisms mediating this effect, particularly the potential role of insulin, are uncertain. Hyperinsulinaemia has been reported to slow gastric emptying in normal subjects during euglycaemia. The purpose of this study was to evaluate the effect of euglycaemic hyperinsulinaemia on gastric emptying in Type I (insulin-dependent) and Type II (noninsulin-dependent) diabetes mellitus. In six patients with uncomplicated Type I and eight patients with uncomplicated Type II diabetes mellitus, measurements of gastric emptying were done on 2 separate days. No patients had gastrointestinal symptoms or cardiovascular autonomic neuropathy. The insulin infusion rate was $40 \mathrm{mU} \cdot \mathrm{m}^{-2} \cdot \mathrm{min}^{-1}$ on one day and $80 \mathrm{mU} \cdot \mathrm{m}^{-2} \cdot \mathrm{min}^{-1}$ on the other. Gastric emptying and intragastric meal distribution were measured using a scintigraphic technique for $3 \mathrm{~h}$ after ingestion of a mixed solid/liquid meal and results compared with a range established in normal volunteers. In both Type I and Type II patients the serum insulin concentration had no effect on gastric emptying or intragastric meal distribution of solids or liquids. When gastric emptying during insulin infusion rates of $40 \mathrm{mU} \cdot \mathrm{m}^{-2} \cdot \mathrm{min}^{-1}$ and $80 \mathrm{mU} \cdot \mathrm{m}^{-2} \cdot \mathrm{min}^{-1}$ were compared the solid $\mathrm{T}_{50}$ was $137.8 \pm 24.6 \mathrm{~min}$ vs $128.7 \pm 24.3 \mathrm{~min}$ and liquid $\mathrm{T}_{50}$ was $36.7 \pm 19.4 \mathrm{~min}$ vs $40.4 \pm 15.7 \mathrm{~min}$ in the Type I patients; the solid $\mathrm{T}_{50}$ was $94.9 \pm 19.1$ vs $86.1 \pm 10.7 \mathrm{~min}$ and liquid $\mathrm{T}_{50}$ was $21.8 \pm 6.9 \mathrm{~min}$ vs $21.8 \pm 5.9 \mathrm{~min}$ in the Type II patients. We conclude that hyperinsulinaemia during euglycaemia has no notable effect on gastric emptying in patients with uncomplicated Type I and Type II diabetes; any effect of insulin on gastric emptying in patients with diabetes is likely to be minimal. [Diabetologia (1999) 42: 365-372]

Keywords Type I diabetes, Type II diabetes, euglycaemia, hyperinsulinaemia, gastric emptying.
The delay in gastric emptying which is evident in about $30-50 \%$ of outpatients with longstanding Type I (insulin-dependent) or Type II (non-insulin-

Received: 3 September 1998 and in revised form: 3 November 1998

Corresponding author: Prof. I. A. Macdonald, School of Biomedical Sciences, University of Nottingham Medical School, Nottingham, NG7 2UH, UK

Abbreviations: CCK, cholecystokinin; GLP-1, glucagon-like peptide-1; RoIs, regions of interest; ALP, amylin and amylinlike peptides; $\mathrm{T}_{50}, 50 \%$ emptying times for solid and liquid; $\mathrm{R}_{100}$, amount of solid in the proximal and distal stomach at $100 \mathrm{~min} ; \mathrm{R}_{10}$, amount of liquid in the proximal and distal stomach at $10 \mathrm{~min}$ dependent) diabetes mellitus has been attributed to irreversible autonomic neuropathy [1-5]. It is now recognised, however, that acute changes in the blood glucose concentration have a major effect on gastric emptying as well as motor function in other regions of the gastrointestinal tract [1,6-14]. The effects of acute hyperglycaemia on gastrointestinal motor function appear to be related directly to the blood glucose concentration [1, 15-19]. Hyperglycaemia slows gastric emptying markedly in patients with Type I and Type II diabetes $[1,7,8]$ and healthy subjects [6]. The mechanisms mediating this effect are uncertain but hyperinsulinaemia might be an important factor. In normal subjects, hyperinsulinaemia, under euglycaemic conditions, slows emptying of 
both solid and liquid meal components of a meal [20, 21], although in the most recent of these studies [20] the magnitude of this slowing was small, albeit statistically significant. The effects of hyperinsulinaemia on gastric emptying in patients with diabetes mellitus have not been evaluated, although there is some evidence that the magnitude of the delay in gastric emptying associated with acute hyperglycaemia is possibly less in diabetic patients when compared with normal subjects $[15,22]$. The effects of hyperglycaemia and hyperinsulinaemia on gastric emptying could also potentially vary between Type I and Type II diabetes; Type I patients having absolute and Type II patients relative insulin deficiency.

The effects of hyperglycaemia (and hyperinsulinaemia) on gastric emptying might be mediated by changes in the secretion of gastrointestinal hormones. There is evidence that cholecystokinin (CCK) $[23,24]$ and glucagon-like peptide-1 (GLP-1) [25-27] are important in the regulation of gastric emptying. Amylin, which is co-secreted with insulin [28], might slow gastric emptying $[29,30]$.

The purpose of this study was to evaluate the effects of euglycaemic hyperinsulinaemia on gastric emptying, intragastric meal distribution and serum concentrations of CCK, GLP-1 and amylin in patients with uncomplicated Type I and Type II diabetes.

\section{Subjects and methods}

Subjects. We studied six men with Type I diabetes mellitus (weight $72.9 \pm 8.7 \mathrm{~kg}$, range 57.3-82.5, BMI $23.5 \pm 2.7 \mathrm{~kg} / \mathrm{m}^{2}$, mean \pm SD), aged $34.3 \pm 9.4$ years (range 23-47) and eight men with Type II diabetes mellitus (weight $95.5 \pm 11.5 \mathrm{~kg}$, range $82.5-117.2$, BMI $31.7 \pm 3.8 \mathrm{~kg} / \mathrm{m}^{2}$ ), aged $43.3 \pm 7.9$ years (range 31-53). The two groups were not matched. The Type II patients tended to be older $(p=0.078)$ and had a greater BMI ( $p=0.0007)$ than the Type I patients. All subjects were ambulatory out patients attending the Diabetic Clinic at Queen's Medical Centre. None reported gastrointestinal symptoms, had a past history of gastrointestinal surgery or was taking medication other than insulin or oral hypoglycaemic agents. Of the Type II patients two were taking insulin and four were on oral hypoglycaemic agents (1 on metformin, 1 on glibenclamide, 1 on gliclazide and 1 on both glibenclamide and metformin). None had autonomic neuropathy, as assessed clinically and by tests of cardiovascular reflexes, including the heart rate response to the valsalva manoeuvre, during deep breathing, and to standing ("30:15" ratio) [31]. In the Type I patients the duration of diabetes was $16.7 \pm 10.1$ years and in the Type II patients the duration of known diabetes was $4.1 \pm 2.1$ years $(p<0.005)$. There was no difference in glycosylated haemoglobin $\left(\mathrm{HbA}_{1 \mathrm{c}}\right)$ between the two groups (Type I: $7.1 \pm 0.6 \%$, Type II: $7.0 \pm 1.4 \%$ ). Informed consent was obtained from all patients. The study protocol was approved by the British Department of Health (Administration of Radioactive Substances Advisory Committee) and the Research Ethics Committee of the University Hospital, Queen's Medical Centre, Nottingham.
Protocol. Patients attended the Department of Medical Physics at $0830 \mathrm{~h}$ on two separate days after an overnight fast. The two studies were separated by at least a week. Each patient was asked to abstain from smoking, alcohol and any beverage which contained caffeine (including coffee, tea and soft drinks) for at least $18 \mathrm{~h}$ prior to each test. The insulin-treated patients (including the two Type II patients who were on insulin) omitted their morning insulin injection and the Type II patients omitted the morning dose of oral hypoglycaemic agent(s). On arrival at the laboratory the fasting blood glucose was less than $10 \mathrm{mmol} / \mathrm{l}$ in all patients. One cannula was inserted into an antecubital vein for infusion of glucose and insulin and another, retrogradely, into a vein on the dorsum of the dominant hand. The latter was kept patent with a slow infusion of $0.9 \%$ $\mathrm{NaCl}$ and the hand rested in a heated box $\left(55-60^{\circ} \mathrm{C}\right)$ so that "arterialized" venous blood samples could be obtained [20].

Low-activity radioactive anatomical markers $\left({ }^{99 \mathrm{~m}} \mathrm{Tc}\right)$ were attached to the surface of the patients' skin, anteriorly and posteriorly. At $0 \mathrm{~min}$ (approximately $1100 \mathrm{~h}$ ) each subject ate, within $10 \mathrm{~min}$, a standard meal consisting of a pancake $(46 \%$ carbohydrate, $26 \%$ fat, $10 \%$ protein) labelled with $3 \mathrm{MBq}$ non-absorbable Tc-99m-ion exchange resin, followed by a low fat milkshake ( $11 \%$ carbohydrate, $4 \%$ fat, $3 \%$ protein) labelled with $0.5 \mathrm{MBq}$ non-absorbable ${ }^{111}$ In-DTPA, providing a total of $400 \mathrm{kcal}$ (the milkshake containing $69 \mathrm{kcal}$ ). While the subject stood, $30 \mathrm{~s}$ anterior and posterior images of the stomach were acquired every $10-20 \mathrm{~min}$ for $3 \mathrm{~h}$, using an IGE maxi-camera II gamma camera (IGE Medical Systems, Slough, UK) fitted with a medium-energy general purpose collimator [32]. The gamma camera was linked to a dedicated $\mathrm{Nu}$ clear Diagnostics computer system. Each subject remained seated between periods of data acquisition. The geometric mean of counts in anterior and posterior gastric regions of interest (ROIs) was calculated and corrected for background radiation, isotope decay and Compton scatter. The total stomach region of interest was subsequently divided into proximal and distal regions - the proximal region corresponding to the fundus and proximal corpus and the distal region representing the antrum and distal corpus [33]. Gastric emptying curves (expressed as percent of the maximum content of the total stomach) were derived for total, proximal and distal stomach regions of interest. For the total stomach the $50 \%$ emptying times for solid and liquid $\left(\mathrm{T}_{50}\right)$ were obtained. In our laboratory the $\mathrm{CV}$ in normal subjects is $13 \%$ for the solid $\mathrm{T}_{50}$ and $28 \%$ for the liquid $\mathrm{T}_{50}$ [34]. The amount of the solid component of the meal in the proximal and distal stomach at $100 \mathrm{~min}\left(\mathrm{R}_{100}\right)$ and the amount of liquid in the proximal and distal stomach at $10 \mathrm{~min}\left(\mathrm{R}_{10}\right)$ were also calculated. Gastric emptying results were compared with those obtained in 10 healthy male volunteers (weight $79.2 \pm 8.2 \mathrm{~kg}$, range 61.8-86.5, BMI $25.5 \pm 2.5$ $\mathrm{kg} / \mathrm{m}^{2}$, mean $\pm \mathrm{SD}$ ), aged $23.6 \pm 3.4$ years $(20-32)$ who underwent measurements of gastric emptying during euglycaemic hyperinsulinaemia, with an insulin infusion rate of $40 \mathrm{mU}$. $\mathrm{m}^{-2} \cdot \mathrm{min}^{-1}$. The results of gastric emptying in these subjects have been reported previously [20]. In this latter group the solid $\mathrm{T}_{50}$ was $149.6 \pm 30.7 \mathrm{~min}$ (range $92-195 \mathrm{~min}$ ) and proximal and distal $R_{100}$ were $53 \pm 10 \%$ and $14 \pm 5 \%$. For the liquid component of the meal the $\mathrm{T}_{50}$ was $39.8 \pm 13.9 \mathrm{~min}$ (range 23-66 min) and proximal and distal $\mathrm{R}_{10}$ were $61 \pm 11 \%$ and $22 \pm 5 \%$ respectively. Gastric emptying in the diabetic patients was considered to be abnormal when it was outside the range in the ten control subjects. The control group was younger $(p<0.05)$ and lighter $(p<0.05)$ than the Type II patients, and younger $(p<0.05)$ than the Type I patients.

Euglycaemic, hyperinsulinaemic clamps were carried out according to the method of De Fronzo et al. [35]. Short-acting insulin (Human Actrapid, Novo Nordisk, Copenhagen, Den- 
mark) was mixed in $0.9 \% \mathrm{NaCl}$, containing $2 \mathrm{ml}$ of the subject's blood, to a concentration of $1 \mathrm{U} / \mathrm{ml}$. The insulin infusion rate was $40 \mathrm{mU} \cdot \mathrm{m}^{-2} \cdot \mathrm{min}^{-1}$ on one day and $80 \mathrm{mU} \cdot \mathrm{m}^{-2} \cdot \mathrm{min}^{-1}$ on the other; the order of the two studies was randomised and they were done in single blind fashion. After a 10 min priming infusion, insulin was infused continuously and when the blood glucose concentration reached $5 \mathrm{mmol} / \mathrm{l}, 20 \%$ dextrose was started at $5.56 \mu \mathrm{mol} \cdot \mathrm{kg}^{-1} \cdot \mathrm{min}^{-1}$. The glucose infusion rate was then adjusted to maintain the blood glucose concentration at $4.5-5.0 \mathrm{mmol} / \mathrm{l}$ for at least $60 \mathrm{~min}$ before each subject ate the test meal, to ensure a steady state glucose infusion rate. After the meal, the rate of glucose infusion was adjusted to maintain the blood glucose concentration within the normal postprandial range $(6-10 \mathrm{mmol} / \mathrm{l})$, while the insulin infusion was continued at the same rate. Blood glucose concentrations were measured every $10 \mathrm{~min}$ with a glucose oxidase method using a Yellow Springs Analyser (Yellow Springs, Ohio, USA); CV for the assay was $3 \%$. Blood was withdrawn at $-30,0,20,30,40,60,90,120,150$ and $180 \mathrm{~min}$ for measurements of serum insulin, CCK, GLP-1 and amylin.

Hormone measurements. Insulin was measured by radioimmunoassay (Diagnostic Products Corporation, Los Angeles, Calif., USA, inter-assay CV $7.4 \%$ at $114 \mathrm{mU} / \mathrm{l})$.

C-peptide was measured by an ELISA based on two monoclonal antibodies (Dako Diagnostics Ltd, Ely, Cambridgeshire, UK). The lower limit of detection was less than $0.05 \mathrm{nmol} / \mathrm{l}$. The inter-assay CV was $3.87-8.2 \%$.

Glucagon-like peptide-1 (GLP-1) was measured in extracts of serum by radioimmunoassay with synthetic GLP-1 (7-36) amide (Bachem Ltd., Saffron Walden, Essex, UK) as the assay standard, antibody code R 600-8 (final dilution 1:30 000), and synthetic GLP-1 labelled by chloramine-T method and purified by reverse phase high-performance liquid chromatography. The antiserum used did not cross-react with other known gut or brain peptides. The sensitivity of the assay was $9 \mathrm{pmol} / \mathrm{l}$ (30 pg/ml); the inter-assay CV was $11 \%$ and the intra-assay $\mathrm{CV}$ was $8 \%$ at $45 \mathrm{pmol} / \mathrm{l}(150 \mathrm{pg} / \mathrm{ml})$.

Cholecystokinin (CCK) was measured by radioimmunoassay with synthetic CCK8 (sulphated) (Bachem, UK) as the assay standard, antibody code R7 (3) (final dilution 1:100 000). Serum was extracted using ethanol, shaken, centrifuged and the supernatant dried under an air stream. This was reconstituted in $500 \mu \mathrm{l}$ assay buffer (phosphate buffer $0.04 \mathrm{~mol} / 1+0.2 \mathrm{~g} \%$ gelatin and $0.16 \mathrm{~g} \%$ EDTA). Bolton \& Hunter [36] labelled ${ }^{125} \mathrm{I}-$ CCK8 s radiolabel (Amersham Life Science Ltd., Little Chalfont, Bucks, UK) and antiserum, raised in rabbit to CCK8s, conjugated to ovalbumin using carbodiimide, were used. The intraassay $\mathrm{CV}$ was $8.2 \%$ and $6.6 \%$ at $4.37 \mathrm{pmol} / \mathrm{l}$ and $13.12 \mathrm{pmol} / \mathrm{l} \mathrm{re}-$ spectively and the inter-assay CV was $13.3 \%$ and $11.5 \%$ at 4.37 $\mathrm{pmol} / \mathrm{l}$ and $13.13 \mathrm{pmol} / \mathrm{l}$ respectively with lower limit of detection of $1.31 \mathrm{pmol} / \mathrm{l}$. The relative crossreactivity with gastrin 17 , pentagastrin, CCK/gastrin 4 was less than 0.001 .

Amylin and amylin-like peptides (ALP) were measured using two-site sandwich ELISA with capture antibodies F024 and F002 respectively (Amylin Pharmaceuticals Inc., San Diego, USA). Interassay CVs were less than $15 \%$ across the assay range. Minimum detectable amylin and ALP concentrations were 1.9 and $2.7 \mathrm{pmol} / \mathrm{l}$.

Statistical analysis. In one subject (in the Type I group) data for liquid gastric emptying were not obtained on one day because of a technical error. Another Type I subject was found to have very high insulin results on both study days, was tested for insulin antibodies and found to have a very high titre. Free insulin concentrations were not measured and his results were, accordingly, excluded from the insulin analysis.
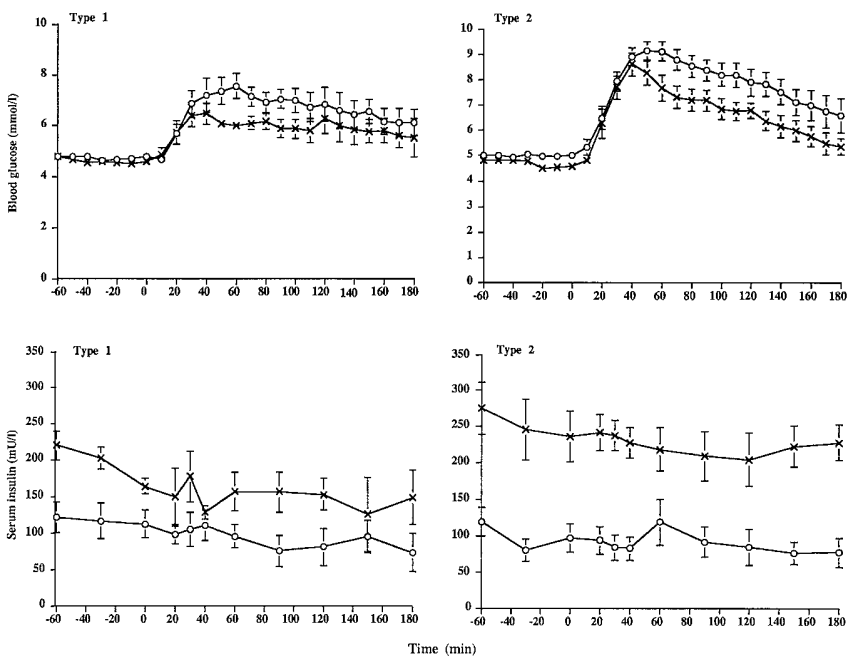

Fig. 1. Blood glucose and insulin profile during the $40 \mathrm{mU} \cdot \mathrm{m}^{-2} \cdot \mathrm{min}^{-1}(-\mathrm{o}-)$ and $80 \mathrm{mU} \cdot \mathrm{m}^{-2} \cdot \mathrm{min}^{-1}(-\mathrm{x}-)$ insulin clamps in the Type I and Type II patients. There were no significant differences in the blood glucose profile on the two experimental days

All biochemical data were analysed using Repeated Measures Analysis of Variance; treatment-time interactions were evaluated to determine the effect of the $40 \mathrm{mU} \cdot \mathrm{m}^{-2} \cdot \mathrm{min}^{-1}$ insulin infusion rate compared with the $80 \mathrm{mU} \cdot \mathrm{m}^{-2} \cdot \mathrm{min}^{-1}$ insulin infusion rate over time. The Mann-Whitney $U$ test for nonparametric data was used to compare means between the Type I and Type II diabetic patients. A $p$ value less than 0.05 was considered significant in all analyses. Data are shown as mean values $\pm \mathrm{SD}$.

\section{Results}

Blood glucose, serum insulin and C-peptide. There were no great differences in the blood glucose profile on the two experimental days (Fig.1), although postprandial blood glucose concentrations tended to be higher when insulin was infused at $40 \mathrm{mU}$. $\mathrm{m}^{-2} \cdot \mathrm{min}^{-1}$ when compared with $80 \mathrm{mU} \cdot \mathrm{m}^{-2} \cdot \mathrm{min}^{-1}$ $(p=0.06$ for the Type I group and $p=0.14$ for the Type II group). In the Type I group the peak blood glucose was $7.6 \pm 1.2 \mathrm{mmol} / \mathrm{l}$ at $60 \mathrm{~min}$ during the $40 \mathrm{mU} \cdot \mathrm{m}^{-2} \cdot \mathrm{min}^{-1}$ insulin experiment and $6.5 \pm$ $1.0 \mathrm{mmo} / \mathrm{l}$ at $40 \mathrm{~min}$ during the $80 \mathrm{mU} \cdot \mathrm{m}^{-2} \cdot \mathrm{min}^{-1} \mathrm{in}$ sulin experiment. The corresponding values in the Type II group were $9.2 \pm 1.0 \mathrm{mmol} / \mathrm{l}$ at $50 \mathrm{~min}$ and $8.6 \pm 1.0 \mathrm{mmol} / \mathrm{l}$ at $40 \mathrm{~min}$ (Fig. 1 ).

In the Type I group mean postprandial insulin concentrations were $92.8 \pm 13.6 \mathrm{mU} / \mathrm{l}$ and $150.5 \pm$ $16.2 \mathrm{mU} / \mathrm{l}$ during the $40 \mathrm{mU} \cdot \mathrm{m}^{-2} \cdot \mathrm{min}^{-1}$ and $80 \mathrm{mU} \cdot \mathrm{m}^{-2} \cdot \mathrm{min}^{-1}$ insulin infusions respectively $(p=0.013)$; for the Type II group the mean postprandial insulin concentrations were $89.4 \pm 13.6 \mathrm{mU} / \mathrm{l}$ and $224.4 \pm 12.7 \mathrm{mU} / \mathrm{l}(p=0.0002)$. During the $80 \mathrm{mU}$. $\mathrm{m}^{-2} \cdot \mathrm{min}^{-1}$ infusion serum insulin concentrations were higher $(p=0.03)$ in the Type II than the Type I 

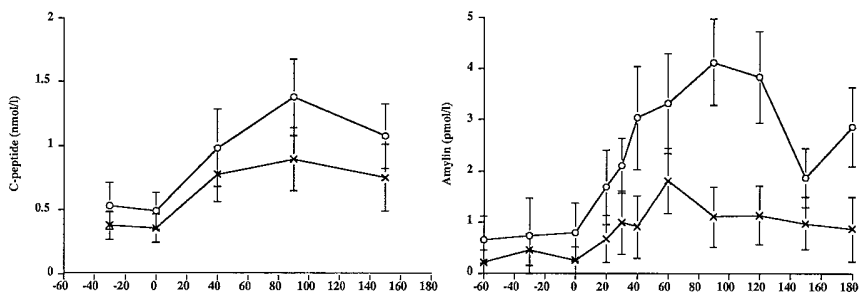

Time (min)

Fig. 2. C-peptide and amylin results in the Type II patients. Cpeptide concentrations were low before the meal and rose $(p=0.0002)$ after it, the response being greater $(p=0.0001)$ during the $40 \mathrm{mU} \cdot \mathrm{m}^{-2} \cdot \mathrm{min}^{-1}$ insulin infusion $(-\mathrm{o}-)$ compared with the $80 \mathrm{mU} \cdot \mathrm{m}^{-2} \cdot \mathrm{min}^{-1}$ infusion $(-\mathrm{x}-)$. There was a rise in serum amylin $(p<0.0001)$ after the meal and this response was greater when the insulin infusion rate was $40 \mathrm{mU}$. $\mathrm{m}^{-2} \cdot \min ^{-1}(-\mathrm{o}-)(p=0.002)$

patients whereas there was no difference between the two groups during the $40 \mathrm{mU} \cdot \mathrm{m}^{-2} \cdot \mathrm{min}^{-1}$ infusion. There was no significant change in serum insulin following the meal in either the Type I or Type II patients.

In the Type II patients C-peptide concentrations were low before the meal and rose $(\mathrm{F}=10.8$, $p=0.0002$, treatment-time interaction) after it, the response being greater $(\mathrm{F}=881.3, p=0.0001$, treatment factor) during the $40 \mathrm{mU} \cdot \mathrm{m}^{-2} \cdot \mathrm{min}^{-1}$ insulin infusion when compared with the $80 \mathrm{mU} \cdot \mathrm{m}^{-2} \cdot \mathrm{min}^{-1}$ infusion (Fig. 2).

Solid and liquid gastric emptying. The comparisons of gastric emptying between the Type I and Type II patients and control subjects are presented as these data are of interest and only tentative conclusions are drawn from these observations. There was no important difference in gastric emptying or intragastric distribution of solid or liquid between the Type I patients and the normal volunteers when the insulin infusion rate was $40 \mathrm{mU} \cdot \mathrm{m}^{-2} \cdot \mathrm{min}^{-1}$. Gastric empty-
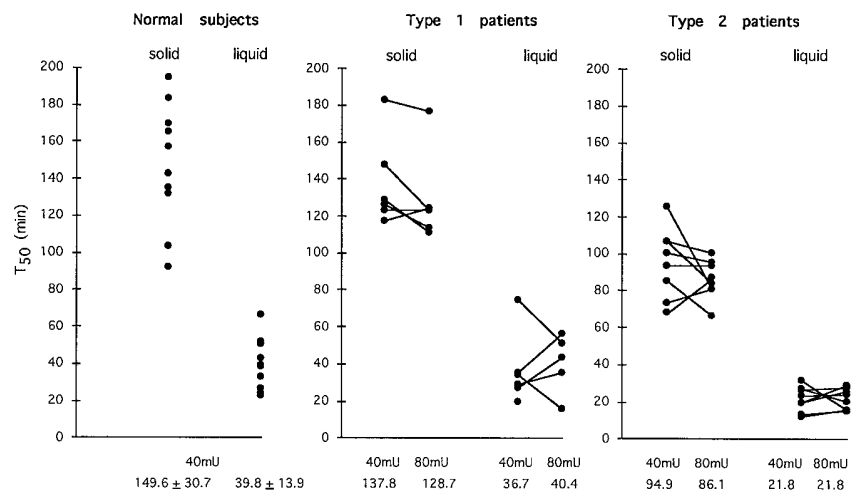

Fig.3. Solid and liquid half-emptying times $\left(\mathrm{T}_{50}\right)$ for the normal subjects, Type I and Type II patients at an insulin infusion rate of $40 \mathrm{mU} \cdot \mathrm{m}^{-2} \cdot \mathrm{min}^{-1}$ and for the Type I and Type II patients at an insulin infusion rate of $80 \mathrm{mU} \cdot \mathrm{m}^{-2} \cdot \mathrm{min}^{-1}$. There was no significant difference in gastric emptying of solid or liquid between the Type I patients and the control subjects when the insulin infusion rate was $40 \mathrm{mU} \cdot \mathrm{m}^{-2} \cdot \mathrm{min}^{-1}$. Gastric emptying was within the control range in all Type I patients

ing was within the control range in all patients. In contrast, in the Type II patients gastric emptying of both solids $(p<0.008)$ and liquids $(p<0.05)$ was faster than in both normal volunteers and Type I patients (Fig. 3). In three of the Type II patients solid emptying $\left(\mathrm{T}_{50}\right)$ was faster than the control range; in four patients liquid emptying $\left(\mathrm{T}_{50}\right)$ was more rapid. In the Type II patients the retention of solid in the proximal stomach at $100 \mathrm{~min}\left(\mathrm{R}_{100}\right)$ was less $(p<0.05)$ than in both the control and Type I patients, whereas there was no difference in the retention in the distal stomach at that time. There was no difference in intragastric distribution of the liquid meal between the Type II patients and the two other groups.

In both Type I and Type II patients there was no difference in gastric emptying or intragastric distribution of solids or liquids between the two experiments,

Table 1. Gastric emptying and intragastric meal distribution in Type I, Type II patients and control subjects at an insulin infusion rate of $40 \mathrm{mU} \cdot \mathrm{m}^{2} \cdot \mathrm{min}^{-1}$ and in Type I and Type II patients at an insulin infusion rate of $80 \mathrm{mU} \cdot \mathrm{m}^{2} \cdot \mathrm{min}^{-1}$

\begin{tabular}{|c|c|c|c|c|c|}
\hline & \multicolumn{3}{|c|}{ Insulin infusion rate of $40 \mathrm{mU} \cdot \mathrm{m}^{2} \cdot \mathrm{min}^{-1}$} & \multicolumn{2}{|c|}{ Insulin infusion rate of $80 \mathrm{mU} \cdot \mathrm{m}^{2} \cdot \mathrm{min}^{-1}$} \\
\hline & Normals & Type I & Type II & Type I & Type II \\
\hline $\begin{array}{l}\text { Total stomach } \\
\mathrm{T}_{50} \text { solid (min) } \\
\mathrm{T}_{50} \text { liquid }(\mathrm{min})\end{array}$ & $\begin{array}{r}149.6 \pm 30.7 \\
39.8 \pm 13.9\end{array}$ & $\begin{array}{r}137.8 \pm 24.6 \\
36.7 \pm 19.4\end{array}$ & $\begin{array}{l}94.9 \pm 19.1^{\mathrm{b}} \\
21.8 \pm 6.9^{\mathrm{a}}\end{array}$ & $\begin{array}{r}128.7 \pm 24.3 \\
40.4 \pm 15.7\end{array}$ & $\begin{array}{l}86.1 \pm 10.7^{\mathrm{d}} \\
21.8 \pm 5.9^{\mathrm{c}}\end{array}$ \\
\hline $\begin{array}{l}\text { Proximal stomach } \\
\mathrm{R}_{100 \text { prox }} \text { solid (\%) } \\
\mathrm{R}_{10 \text { prox }} \text { liquid (\%) }\end{array}$ & $\begin{array}{l}53 \pm 10 \\
61 \pm 11\end{array}$ & $\begin{array}{l}44 \pm 6 \\
59 \pm 15\end{array}$ & $\begin{array}{l}33 \pm 8^{e} \\
53 \pm 16\end{array}$ & $\begin{array}{l}42 \pm 6 \\
58 \pm 13\end{array}$ & $\begin{array}{l}24 \pm 5^{\mathrm{e}} \\
51 \pm 14\end{array}$ \\
\hline
\end{tabular}

the proximal and distal stomach at $10 \mathrm{~min}$ 

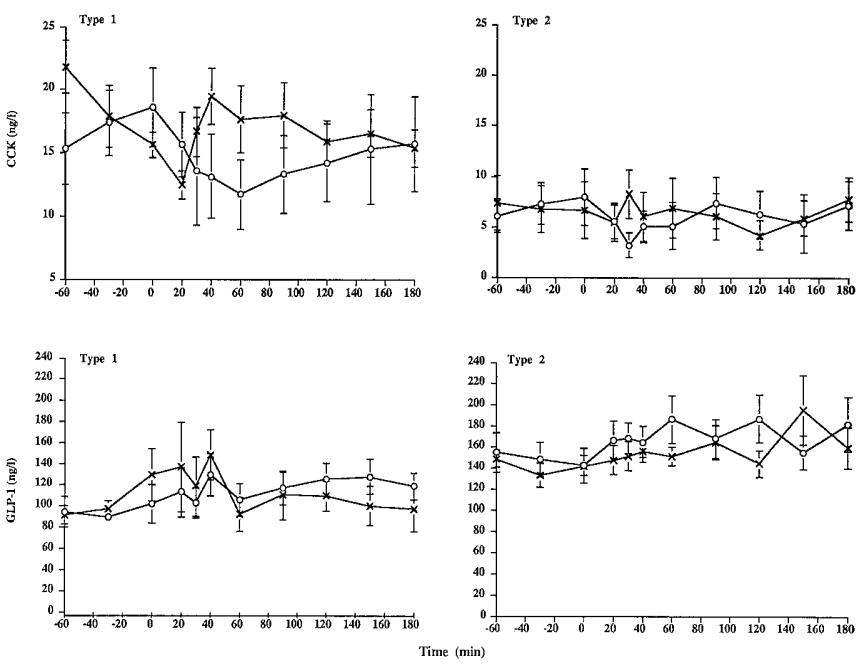

Fig. 4. CCK and GLP-1 results in the Type I and Type II patients. In both the Type I and Type II patients the insulin infusion rate had no effect on serum concentrations of CCK or GLP-1

that is, the serum insulin concentration had no effect on gastric emptying.

Gastrointestinal hormones. In both the Type I and Type II patients the insulin infusion rate had no effect on serum concentrations of CCK or GLP-1. In contrast, in the Type II patients there was a rise in serum amylin $(\mathrm{F}=15.2, p<0.0001$, treatment-time interaction) and ALP (F $=16.5, p<0.0001$, treatment-time interaction, data not shown) after the meal and this response was greater when the insulin infusion rate was $40 \mathrm{mU} \cdot \mathrm{m}^{-2} \cdot \min ^{-1}(\mathrm{~F}=7.5, p=0.04$ for ALP and $\mathrm{F}=8.8, p=0.02$ for amylin, treatment factor). As expected, the Type I subjects had undetectable amylin and ALP values and there was no response following the meal on either day. At both insulin infusion rates serum CCK was greater $(p<0.005)$ while serum GLP-1 was less $(p<0.05)$ in the Type I patients than the Type II patients.

\section{Discussion}

Our study is the first to evaluate the effect of variations in the serum insulin concentration on gastrointestinal motor function in patients with diabetes. The results indicate that hyperinsulinaemia per se, in the absence of hyperglycaemia, has no significant effect on gastric emptying in patients with uncomplicated Type I or Type II diabetes. This suggests that the substantial retardation of gastric emptying induced by hyperglycaemia in both normal subjects [6] and patients with diabetes mellitus $[1,7,8]$ is not mediated by an increase in insulin secretion.

The effects of insulin on gastrointestinal motor function are controversial [16, 20, 21, 37-40]. The se- rum insulin concentrations that we evaluated are comparable with those achieved during "marked" and "physiological" hyperglycaemia in normal subjects $[16,20,21]$. In the healthy volunteers, the postprandial serum insulin concentrations during the saline infusion approximated the serum insulin concentrations in the diabetic patients during the $40 \mathrm{mU} \cdot \mathrm{m}^{-2} \cdot \mathrm{min}^{-1}$ insulin infusion and in the diabetic patients, the serum insulin concentrations during the $80 \mathrm{mU} \cdot \mathrm{m}^{-2} \cdot \mathrm{min}^{-1}$ insulin infusion approximated the postprandial serum insulin concentrations in the healthy volunteers during the $40 \mathrm{mU} \cdot \mathrm{m}^{-2} \cdot \mathrm{min}^{-1}$ insulin infusion (which included endogenous insulin secretion). Not surprisingly, there was a non-significant trend for lower blood glucose concentrations during the $80 \mathrm{mU} \cdot \mathrm{m}^{-2} \cdot \mathrm{min}^{-1}$ insulin infusion when compared with the $40 \mathrm{mU} \cdot \mathrm{m}^{-2} \cdot \mathrm{min}^{-1}$ insulin infusion, and a modest postprandial increase in blood glucose concentrations. These issues are unlikely to have influenced the results. A non-hyperinsulinaemic control (saline infusion) study was not included because the inevitable occurrence of marked hyperglycaemia would have precluded interpretation as hyperglycaemia is known to slow gastric emptying under these conditions $[1,7,8]$. We cannot exclude the possibility that serum insulin concentrations that are lower or higher than those evaluated may affect gastric emptying, or that the effects of insulin differ between normal subjects and patients with diabetes. Our observations, however, are consistent with the majority of previous studies that have evaluated the effects of insulin on gut motor function in normal subjects; in most cases in which an effect of insulin was evident, its magnitude was relatively small [20, 39]. Furthermore, it has been shown that the effects of hyperglycaemia on gastric emptying, antral motility [1,15-17], gallbladder emptying [19] and anorectal motility [18] are related directly to the blood glucose concentration, e.g. postprandial antral motility is suppressed more at a blood glucose of $230 \mathrm{mg} / \mathrm{dl}$ (12.8 mmol/l) compared with $175 \mathrm{mg} / \mathrm{dl}(9.7 \mathrm{mmol} / \mathrm{l})$ [16]. These observations reinforce the concept that insulin concentrations lower than those examined would almost certainly not affect gastric emptying in patients with diabetes.

In our previous study which assessed the effect of euglycaemic hyperinsulinaemia on gastric emptying in normal subjects, gastric emptying of both solids and liquids was slower during hyperinsulinaemia, but the difference, albeit statistically significant, was modest (solid $\mathrm{T}_{50} 149.6 \pm 30.7$ vs $129 \pm 26.2 \mathrm{~min}$, liquid $\mathrm{T}_{50} 39.8 \pm 13.9$ vs $30.1 \pm 12.5 \mathrm{~min}$ ). It has been reported that in normal subjects postprandial antral motility is suppressed by hyperglycaemia, but not euglycaemic hyperinsulinaemia [16]. In contrast to this another study reported that in normal subjects hyperinsulinaemia per se abolishes antral phase III and shortens duodenal phase III [37]. The slowing of 
small intestinal transit by marked hyperglycaemia $[11,12]$ is not replicated by hyperinsulinaemia [39] and, similarly, it has been reported that acute hyperglycaemia, but not secondary hyperinsulinaemia, blunts mechanoreceptor-mediated gastrocolonic responses [40], and the rectoanal inhibitory reflex [38].

It should be recognized that we studied a relatively small number of patients who were selected to have uncomplicated diabetes mellitus and good glycaemic control; gastric emptying was not delayed in any patient. It seems most unlikely that hyperinsulinaemia would affect gastric emptying in diabetic patients who have gastroparesis or autonomic neuropathy or both but we did not address this issue.

There were substantial differences in gastric emptying and serum concentrations of CCK, GLP-1 and amylin between the Type I and Type II patients. Only tentative conclusions should be drawn from these observations, however, as both Type I and Type II patients were highly selected and there were substantial differences between the two groups as well as between these groups and the normal volunteers. For example, the Type II patients were, not surprisingly, heavier and tended to be older than the Type I patients. Furthermore, the number of control subjects was relatively small. Our observations that gastric emptying from the total and proximal stomach was faster in the Type II patients than in both Type I patients and control subjects is, however, consistent with the concept that gastric emptying is frequently accelerated in "early" Type II diabetes [41-43]. While the prevalence of delayed gastric emptying in patients with longstanding Type II diabetes appears comparable with that in Type I diabetes [2, 4, 7], there is substantial controversy as to the prevalence of disordered gastric emptying in patients with so-called "early" Type II diabetes [41-44] and a number of studies have suggested that gastric emptying may be more rapid in this group [41-43]. It should, however, be recognised that a substantial deficiency of all studies which have evaluated the prevalence of disordered gastric emptying in Type II diabetes is that blood glucose concentrations were not stabilised in the euglycaemic range [41-44].

CCK plays a role in the regulation of gastric emptying $[23,24]$ and appetite $[45,46]$. In normal subjects, acute hyperglycaemia does not affect CCK secretion induced by intraduodenal fat [11]. Reports on the effects of diabetes mellitus on CCK secretion are controversial. It has been reported that both basal and postprandial CCK concentrations are normal in Type I and Type II diabetic patients without autonomic neuropathy [47] and that the CCK response to a meal is increased in patients with autonomic neuropathy [47-49]; in contrast, it has been reported that postprandial CCK concentrations are lower in Type II patients when compared with normal subjects [50]. We observed that serum CCK concentrations were lower in the Type II than the Type I patients; accordingly the possibility that more rapid gastric emptying in Type II diabetes mellitus might be related to a reduction in CCK secretion warrants evaluation. The higher serum GLP-1 concentrations in the Type II patients has been noted previously [51, 52]; it has been suggested that the reduction in the incretin effect in these patients possibly reflects insensitivity of the beta-cell to GLP-1 [53].

There was a notable rise in both C-peptide and amylin after the meal in the Type II patients, the response being greater when the insulin infusion rate was $40 \mathrm{mU} \cdot \mathrm{m}^{-2} \cdot \mathrm{min}^{-1}$. As amylin is co-secreted with insulin, these observations are indicative of an increase in endogenous insulin secretion despite the absence of significant change in serum insulin concentrations. It has been demonstrated in normal subjects that raising serum insulin does not prevent endogenous insulin release $[20,21]$. It should be acknowledged that we did not look at the effect of an insulin infusion rate of $80 \mathrm{mU} \cdot \mathrm{m}^{-2} \cdot \mathrm{min}^{-1}$ in our healthy volunteers so we cannot be sure that very high insulin concentrations would not suppress the beta-cell. The demonstration that postprandial concentrations of both C-peptide and amylin were lower at an insulin infusion rate of $80 \mathrm{mU} \cdot \mathrm{m}^{-2} \cdot \mathrm{min}^{-1}$ suggests that in Type II diabetes serum insulin concentrations influence insulin secretion. On the other hand, the higher blood glucose concentrations at an insulin infusion rate of $40 \mathrm{mU} \cdot \mathrm{m}^{-2} \cdot \mathrm{min}^{-1}$ could potentially account for a higher secretory drive on both endogenous insulin and amylin.

We conclude that euglycaemic hyperinsulinaemia has little or no effect on gastric emptying of a solid and liquid meal in patients with uncomplicated Type I and Type II diabetes mellitus. Another potential mechanism by which hyperglycaemia slows gastric emptying is possibly a central nervous system effect which is supported by animal and human studies; a direct effect on smooth muscle seems unlikely as both smooth muscle stimulation (pylorus, small intestine) $[10,12]$ and inhibition (proximal stomach, antrum) $[9,13,14,16]$ occur during hyperglycaemia. Changes in vagal activity and the secretion of other gastrointestinal hormones (motilin, glucagon, GIP) and myogenic mechanisms could be important.

Acknowledgements. We thank C. Caldwell (Department of Medicine, Royal Victoria Hospital, Belfast, UK) for technical assistance for the GLP-1 assays, P. Riley (Cripps computing centre, University of Nottingham, Nottingham, UK) for statistical advice and Dr. M. Payne (Oxford Diabetes Research Laboratories, Oxford, UK) and Amylin Pharmaceuticals Inc. (San Diego, Calif., USA) and Amylin Europe Ltd (Oxford, UK) for the amylin and ALP assays and Dr. K. Jones (Department of Medicine, Royal Adelaide Hospital, Adelaide, South Australia) for statistical help. This work was supported in part by the National Health and Medical Research Council of Australia and the Wellcome Trust, UK. 


\section{References}

1. Fraser R, Horowitz M, Maddox AF, Harding PE, Chatterton BE, Dent J (1990) Hyperglycaemia slows gastric emptying in Type I (insulin-dependent) diabetes mellitus. Diabetologia 33: 675-680

2. Horowitz M, Maddox AF, Wishart JM, Harding PE, Chatterton BE, Shearman DJC (1991) Relationships between oesophageal transit and solid and liquid gastric emptying in diabetes mellitus. Eur J Nucl Med 18: 229-234

3. Keshavarzian A, Iber FL, Vaeth J (1987) Gastric emptying in patients with insulin-requiring diabetes mellitus. Am J Gastroenterol 82: 29-35

4. Wegener M, Börsch G, Schaffstein J, Luerweg C, Leverkus F (1990) Gastrointestinal transit disorders in patients with insulin-treated diabetes mellitus. Dig Dis Sci 8: 23-26

5. Rundles RW (1945) Diabetic neuropathy: general review with report of 125 cases. Medicine 24: 111-160

6. MacGregor I, Gueller R, Watts H, Meyer J (1976) The effects of acute hyperglycaemia on gastric emptying in man. Gastroenterology 70: 190-196

7. Horowitz M, Harding PE, Maddox A et al. (1989) Gastric and oesophageal emptying in patients with Type II (noninsulin-dependent) diabetes mellitus. Diabetologia 32: 151-159

8. Samsom M, Akkermans LMA, Jebbink RJA, van Isselt H, vanBerge-Henegouwen GP, Smout AJPM (1997) Gastrointestinal motor mechanisms in hyperglycaemia induced delayed gastric emptying in Type I diabetes mellitus. Gut 40: $641-646$

9. Barnett JL, Owyang C (1988) Serum glucose concentrations as a modulator of interdigestive gastric motility. Gastroenterology 94: 739-744

10. Fraser R, Horowitz M, Dent J (1991) Hyperglycaemia stimulates pyloric motility in normal subjects. Gut 32: 475-478

11. De Boer SY, Masclee AAM, Lam WF, Schipper J, Jansen JB, Lamers CB (1993) Hyperglycaemia modulates gallbladder motility and small intestinal transit time in man. Dig Dis Sci 38: 2228-2235

12. Russo A, Fraser R, Horowitz M (1996) The effect of acute hyperglycaemia on small intestinal motility in normal subjects. Diabetologia 39: 984-989

13. Hebbard GS, Sun WM, Dent J, Horowitz M (1996) Hyperglycaemia affects proximal gastric motor and sensory function in normal subjects. Eur J Gastroenterol Hepatol 8: 211-217

14. Hebbard GS, Samsom M, Sun WM, Dent J, Horowitz M (1996) Hyperglycaemia affects proximal gastric motor and sensory function during small intestinal nutrient infusion. Am J Physiol 271:G814-G819

15. Schvarcz E, Palmer M, Aman J, Horowitz M, Stridsberg M, Berne C (1997) Physiological changes in blood glucose affect gastric emptying in normal subjects and patients with insulin-dependent diabetes. Gastroenterology 113: 60-66

16. Hasler WL, Soudah HC, Dulai G, Owyang C (1995) Mediation of hyperglycaemia-induced gastric slow-wave dysrhythmias by endogenous prostaglandins. Gastroenterology 108: 727-736

17. Groop LC, Defronzo RA, Luzi L, Melander A (1989) Hyperglycaemia and absorption of sulphonylurea drugs. Lancet ii: $129-130$

18. Russo A, Sun WM, Sattawatthamrong Y, Fraser R, Horowitz M, Andrews JM, Read NW (1997) Acute hyperglycaemia affects anorectal motor and sensory function in normal subjects. Gut 41: 494-499
19. De Boer SY, Masclee AA, Jebbink MC, Schipper J, Lemkes HH, Jansen JB, Lamers CB (1993) Effect of acute hyperglycaemia on gall bladder contraction induced by cholecystokinin in humans. Gut 34: 1128-1132

20. Kong M-F, King P, Macdonald IA et al. (1998) Effect of euglycaemic hyperinsulinaemia on gastric emptying and gastrointestinal hormone responses in normal subjects. Diabetologia 41: 474-481

21. Eliasson B, Björnsson E, Urbanavicius V et al. (1995) Hyperinsulinaemia impairs gastrointestinal motility and slows carbohydrate absorption. Diabetologia 38: 79-85

22. Dao T, Chee B, Bouvard G, Justum AM, Verwaerde JC, Valla A (1990) Lack of modulation of gastric emptying by acute hyperglycaemia in Type II diabetes mellitus. Gastroenterology 98: A342

23. Liddle RA, Rushakoff RJ, Morita ET, Beccaria L, Carter JD, Goldfine ID (1988) Physiological role for cholecystokinin in reducing postprandial hyperglycaemia in humans. J Clin Invest 81: 1675-1681

24. Liddle RA, Morita ET, Conrad CK, Williams JA (1986) Regulation of gastric emptying in humans by cholecystokinin. J Clin Invest 77: 992-996

25. Wettergren A, Schjoldager B, Mortensen PE, Myhre J, Christiansen J, Holst JJ (1993) Truncated GLP-1 (proglucagon 78-107-Amide) inhibits gastric and pancreatic functions in man. Dig Dis Sci 38: 665-673

26. Gutniak M, Ørskov C, Holst JJ, Ahren B, Efendic S (1992) Antidiabetogenic effect of glucagon-like peptide-1 [7-36 amide] in normal subjects and patients with diabetes. $\mathrm{N}$ Eng J Med 326: 1316-1322

27. Dupré J, Behme MT, Hramiak IM et al. (1995) Glucagonlike peptide 1 reduces postprandial glycaemic excursions in IDDM. Diabetes 44: 626-630

28. Cooper GJS, Willis AC, Clark A, Turner RC, Sim RB, Reid KB (1987) Purification and characterization of a peptide from amyloid-rich pancreases of Type II diabetic patients. Proc Natl Acad Sci USA 84: 8628-8632

29. Kong M-F, King P, Macdonald IA et al. (1997) Infusion of pramlintide, a human amylin analogue, delays gastric emptying in men with IDDM. Diabetologia 40: 82-88

30. Kong M-F, Stubbs TA, King P et al. (1998) The effect of single doses of pramlintide on gastric emptying of two meals in men with IDDM. Diabetologia 41: 577-583

31. Ewing DJ, Clarke BF (1982) Diagnosis and management of diabetic autonomic neuropathy. BMJ 285: 916-918

32. Hardy JG, Perkins AC (1985) Validity of the geometric mean correction in the quantification of whole bowel transit. Nucl Med Commun 6: 217-224

33. Horowitz M, Jones K, Edelbroek MAL, Smout AJPM, Read NW (1993) The effect of posture on gastric emptying and intragastric distribution of oil and aqueous meal components and appetite. Gastroenterology 105: 382-390

34. Kong M-F, Perkins AC, King P, Blackshaw PE, Macdonald IA (1998) Reproducibility of gastric emptying of a pancake and milkshake meal in normal subjects. Nucl Med Commun 19: 77-82

35. DeFronzo RA, Tobin JD, Andres R (1979) Glucose clamp technique: a method for quantifying insulin secretion and resistance. Am J Physiol 237: E214-E223

36. Bolton AE, Hunter WM (1973) Labelling of protein to a high specific radioactivity by conjugation to a ${ }^{125}$ I-containing acylating agent. Biochem J 133: 529-539

37. Björnsson ES, Urbanavicius V, Eliasson B, Attvall S, Smith U, Abrahamsson H (1995) Effects of insulin and betaadrenergic blockade on the migrating motor complex in humans. Scand J Gastroenterol 30: 219-224 
38. Chey WD, Kim M, Hasler WL, Owyang C (1995) Hyperglycaemia alters perception of rectal distention and blunts the rectoanal inhibitory reflex in healthy volunteers. Gastroenterology 108: 1700-1708

39. Gielkens HA, Verkijk M, Frolich M, Lamers CB, Masclee AA (1997) Is the effect of acute hyperglycaemia on interdigestive antroduodenal motility and small-bowel transit mediated by insulin? Eur J Clin Invest 27: 703-710

40. Sims MA, Hasler WL, Chey WD, Kim MS, Owyang C (1995) Hyperglycaemia inhibits mechanoreceptor-mediated gastrocolonic responses and colonic peristaltic reflexes in healthy humans. Gastroenterology 108: 350-359

41. Phillips WT, Schwarz JG, McMahan CA (1992) Rapid gastric emptying of an oral glucose solution in Type II diabetic patients. J Nucl Med 33: 1496-1500

42. Frank JW, Saslow SB, Camilleri M, Thomforde GM, Dinneen S, Rizza RA (1995) Mechanism of accelerated gastric emptying of liquids and hyperglycaemia in patients with Type II diabetes mellitus. Gastroenterology 109: 755-765

43. Schwartz JG, Green GM, Guan D, McMahan CA, Phillips WT (1996) Rapid gastric emptying of a solid pancake meal in Type II diabetic patients. Diabetes Care 19: $468-471$

44. Jones KL, Horowitz M, Carney BI, Wishart JM, Guha S, Green L (1996) Gastric emptying in 'early' non-insulin dependent diabetes mellitus. J Nucl Med 37: 1643-1648

45. Kissileff HR, Pi-Sunyer FX, Thornton J, Smith GP (1981) C-terminal octapeptide of cholecystokinin decreases food intake in man. Am J Clin Nutr 34: 154-160

46. Lieverse RJ, Janson JBMJ, Masclee AAM, Lamers CBHW (1995) Satiety effects of a physiological dose of cholecystokinin in humans. Gut 36: 176-179
47. Glasbrenner B, Dominguez-Munoz E, Riepl RL, Vetsi A, Malfertheiner P (1995) Cholecystokinin and pancreatic polypeptide release in diabetic patients with and without autonomic neuropathy. Dig Dis Sci 40: 406-411

48. Nakano I, Funakoshi A, Shinozaki H et al. (1986) High plasma cholecystokinin response following ingestion of test meal by patients with non-insulin dependent diabetes mellitus. Regul Pept 14: 229-236

49. Mitsukawa T, Takemura J, Ohgo S et al. (1990) Gallbladder function and plasma cholecystokinin levels in diabetes mellitus. Am J Gastroenterol 85: 981-985

50. Rushakoff RA, Goldfine ID, Beccaria LJ, Mathur A, Brand RJ, Liddle RA (1993) Reduced postprandial cholecystokinin (CCK) secretion in patients with noninsulin-dependent diabetes mellitus: evidence for a role for CCK in regulating postprandial hyperglycaemia. J Clin Endocrinol Metab 76: 489-493

51. Ørskov C, Jeppesen J, Madsbad S, Holst JJ (1991) Proglucagon products in plasma of noninsulin-dependent diabetics and nondiabetic controls in the fasting state and after oral glucose and intravenous arginine. J Clin Invest 87: 415-423

52. Nauck MA, Heimesaat MM, Ørskov C, Holst JJ, Ebert R, Creutzfeldt W (1993) Preserved incretin activity of glucagon-like peptide 1 (7-36 amide) but not of synthetic human gastric inhibitory polypeptide in patients with type- 2 diabetes mellitus. J Clin Invest 91: 301-307

53. Byrne MM, Göke B (1996) Human studies with glucagonlike-peptide-1: potential of the gut hormone for clinical use. Diab Med 13: 854-860 